\title{
Merton and Lazarsfeld: Collaboration on Communication Research-Two Papers, Two Research Instruments, and Two Kindred Concepts*
}

\author{
HYNEK JEŘÁBEK** \\ Faculty of Social Sciences, Charles University, Prague
}

\begin{abstract}
This article attempts to thoroughly map the cooperation between R. K. Merton and P. F. Lazarsfeld on communication research in the 1940s. Merton mainly gained fame for his work on theory and Lazarsfeld for his work on methodology, but this article is not interested in the important research results attained by the two researchers independently or in cooperation with other researchers. It concentrates solely on the demonstrable results of their collaboration. The interpersonal influence of the two researchers was key to the development of their concepts, research tools, and theoretical generalisations. Their collaboration in the field of communication research led to the creation of two interlinked research methods-the programme analyser and the focused interview. The conclusions they reached on communication theory in two papers they wrote together and the pair of sociological concepts, 'opinion leaders' and 'influentials', that they developed in the field of interpersonal communication are both still widely used and elaborated on today.

Keywords: opinion leaders, influentials, focused interview, programme analyser, Robert K. Merton, Paul. F. Lazarsfeld, communication research Sociologický časopis/Czech Sociological Review, 2011, Vol. 47, No. 6: 1191-1214
\end{abstract}

\section{Introduction}

This article looks at the decades-long history of collaboration between Robert K. Merton and Paul F. Lazarsfeld on communication research. This period in the lives of both of these social scientists represented just one stage in their scientific careers. Merton was an important sociological theorist and Lazarsfeld an influential methodologist and the inventor of a new model of empirical social research. This article focuses on the fruits of the relatively unusual cooperation betweeen a sociological theorist and an empirical researcher on the construction of a new scientific sub-field-communication research. The article aims to demonstrate

\footnotetext{
* Work on this article was supported by the Grant Agency of the Czech Republic, grant no 404/11/0949.

** Direct all correspondence to: Hynek Jeřábek, Institute of Sociological Studies, Faculty of Social Sciences, Charles University, U Kř́iže 8, 15800 Prague 5, Czech Republic, e-mail: jerabek@fsv.cuni.cz.
} 
how the combination of Lazarsfeld's methodological experience and Merton's theoretical skills boosted the success of their research efforts and what new and important results their cooperation brought to the fields of sociological theory and research methodology. ${ }^{1}$

The article focuses on two papers written jointly by Merton and Lazarsfeld, namely 'Studies in Radio and Film Propaganda' [Merton and Lazarsfeld (1943) 1968] and 'Mass Communication, Popular Taste and Organized Social Action' [Lazarsfeld and Merton (1948) 1971], and discusses two methodological tools developed by Lazarsfeld and Merton, the 'programme analyser' and 'the focused interview', ${ }^{2}$ which were designed to be applied in combination in the field of communication research. Merton and Lazarsfeld's collaboration had a third important result with their development of two concepts: 'opinion leaders', a concept invented and tested by Lazarsfeld, and 'influentials', developed by Merton. Their friendly, everyday cooperation, coordinated and complementary, was significant and important for them, for the field of communications research, and for sociological theory and methodology as a whole. ${ }^{3}$

\section{Recent literature on Lazarsfeld and Merton's contribution to communication research}

There are a number of studies that have discussed the collaboration between Lazarsfeld and Merton in the field of communication theory. Most notably Peter Simonson and Gabriel Weimann [2003] wrote about Lazarsfeld and Merton's 'Mass Communication, Popular Taste, and Organized Social Action', one of the canonic texts in media research, commenting on the 'limited effects paradigm', which was and still is considered to be the most important contribution of the 'Lazarsfeld school' to communication research. They review and provide their own well-argumented contribution to the critical debate from the 1970s and 1980s about the contribution of the 'Columbia school' to communication research.

\footnotetext{
${ }^{1}$ I discuss Lazarsfeld's role in the early stages of communication research and also Merton's 'Mass Persuasion' and 'Patterns of Influence' in my book Paul Lazarsfeld and the Origins of Communications Research published in Czech [Jeřábek 1997]. For more on the methodological issues connected with measuring Lazarsfeld's opinion leaders and the approach to these issues in the works of Gabriel Weimann and Elisabeth Noelle-Neumann see Jeřábek [2003] and Jeřábek [2008].

${ }^{2}$ In some of his papers Merton used the term 'the focussed interview' spelt with two s's. In a retrospective paper Merton once wrote: '. . . to my dismay, the publisher insisted on dropping one of the s's in focussed ...' [Merton 1987: 556]. The reason for two s's' was that in this specific interview the moderator focuses the attention of participants on some specific moments, aspects, or qualities of an evaluated programme or of the discussed topic. And therefore the whole interview is 'the focussed interview'.

${ }^{3}$ Sources important for description and interpretation of this collaboration include two important Festschrifts written by Lazarsfeld [1975] and by Merton [1998].
} 
Simonson and Weimann [2003: 16] sum up that: 'To claim that Lazarsfeld and company taught "that media are not very important in the formation of public opinion" [Gitlin 1978: 207], or that "issues . . . of social structure and economic relations were simply absent" from Columbia research [Hall 1982: 59] is to ignore some of the most important Bureau publications of the 1940s, most particularly "Mass Communication".'

Simonson and Weimann also distinguish between the different roles that Lazarsfeld and Merton probably played in the writing of this essential text: Lazarsfeld, they claim, was inclined to use survey methods and 'analyze effects of media and other inputs on aggregated individual actions', while Merton was more likely 'to situate media within broader social systems and historical contexts' and could offer the right 'analytic concepts' in 'graceful prose' [ibid.: 20]. They claim that the 'Mass Communication' paper is a rejection of technological determinism in mass media influence and a fruitful 'translation' of Lazarsfeldian findings into Mertonian language. Instead of Lazarsfeld's term 'effects of mass media upon society', Merton suggested the 'social functions of mass media', and Merton came up with three concepts to explain the main social functions of mass media: 'the status conferral function', 'the enforcement of social norms', and 'the narcotising dysfunction of mass media' [ibid.: 22-23]. Finally, Simonson and Weimann also defend Lazarsfeld and Merton's 'limited effects paradigm' by pointing out the danger and mistake of simplification made by critics of the paradigm: 'Limited effects does not mean "no effects". It does not mean "weak effects" ... limited effects means that there are limited conditions under which "propaganda for social objectives" might actually have quite powerful persuasive effects.' [ibid.: 29] These are highly pertinent observations, but for the purpose of this article what is especially significant is Simonson and Weimann's identification of the role of each scholar in their collaboration.

Other important papers that have dealt with the collaboration between Merton and Lazarsfeld focus on more general questions. Charles Crothers discusses the links between Merton's theory and Lazarsfeld's methodology and notes the outcome of their joint efforts. In his view, Lazarsfeld and Merton helped to transform sociology into an effective, cumulative discipline [Crothers 1998: 215]. Crothers provides detailed examples of various forms of cooperation between Merton and Lazarsfeld in the paragraphs about their co-careers, co-publishing, co-teaching and co-working [ibid.: 216-219]. While he presents 'mass communication' as the only subject area that they both worked on fully [ibid.: 243], he sees their cooperation much more broadly as collaboration in the fields of theory and methodology, empirical analysis of social action aimed at 'decision-making' processes, and 'as a joint commitment to institution-building to ensure that their goals could be implemented' [ibid.: 249].

Carmelo Lombardo [2004] has also written on this topic, highlighting the importance of the collaboration between Lazarsfeld and Merton in the 1940s and 1950s for the empirical analysis of action and for developing theories about social 
mechanisms. Lombardo notes the parallel scientific findings Lazarsfeld and Merton were reaching, using the same processes and the same data, and he points out how sensitively Lazarsfeld and Merton were able to weave individual and structural elements together to explain social phenomena [ibid.: 143].

Another important source shedding light on the collaboration between Merton and Lazarsfeld are studies addressing Merton's personal contribution to the development of communication theory and Lazarsfeld's contribution to advancing the methodology of communication research. Here I will just touch briefly on these studies as they do not fall entirely within the scope of this article. One example is Simonson's interpretation of Merton's Mass Persuasion [Merton, Fiske and Curtis (1946) 1971] in the foreword he wrote to a new edition of the monograph [Simonson 2004] and another is his most recent book about the history of communication theories [Simonson 2010]. A theoretical analysis of Katz and Lazarsfeld's Personal Influence [1955] might reveal how different their approach was from Merton's work and would thus also uncover the differences between Lazarsfeld's and Merton's concepts.

In his insightful analysis of Merton's contribution to communication research Peter Simonson describes Merton's communication research as "'serendipitous"—unplanned, surprising, but highly productive' [Simonson 2005: 277]. Simonson demonstrates the presence of the attribute of serendipity both when Merton's findings in communication research are isolated from Lazarsfeld's efforts in this field, and when their findings are taken together. To this end he quotes Merton directly: 'Fruitful empirical research not only tests theoretically derived hypotheses; it also originates new hypotheses. This might be termed the "serendipity" component of research, i.e., the discovery, by chance or sagacity, of valid results which were not sought for'; 'Research and theory would need to be married if sociology is to bear legitimate fruit' [Merton (1948) 1968: 157, 171; Simonson 2005: 290].

Were we to isolate the sociological generalisations Merton reached in his own communication research we might be surprised to find that they represent the logical next step from the results and findings of the communication research conducted by Lazarsfeld and Merton together. And this is also the main reason why this article concentrates mainly on the 'combined results' of their work, on the findings in which they influenced each other.

\section{The background to Lazarsfeld and Merton's collaboration on communication research}

Merton $^{4}$ and Lazarsfeld ${ }^{5}$ collaborated for thirty-five years-from 1941 up until the death of Paul F. Lazarsfeld in 1976. They both worked at Columbia University,

\footnotetext{
${ }^{4}$ More about Merton's life and work can be found in Sztompka [1986].

5 Paul Lazarsfeld's best biographers are David Sills [1987] and Paul Neurath [1998]. The
} 
having joined the school at the same time in 1941, when Lazarsfeld was forty and Merton thirty years old. It could be said that they were brought together by a hiring dispute in the Department of Sociology at Columbia University. According to Merton, in 1940 the department was looking to hire a full professor of sociology. Its sociological theorists, led by Robert McIver, and its empirical researchers, led by Robert S. Lynd, were unable to agree on who should fill the post, so the two camps compromised and instead of one full professor they hired two promising researchers: Paul F. Lazarsfeld, as associate professor, and Robert K. Merton, as assistant professor [Merton 1998: 164-165; Neurath 1980: 34].

Before coming to Columbia University, Lazarsfeld had repeatedly collaborated with Robert S. Lynd, the chair of the Department of Sociology at Columbia University. They first met when Lazarsfeld was on a visiting fellowship to the United States in 1933. In 1935 Lynd helped Lazarsfeld to find a job and later, in 1937, recommended him to Hadley Cantril for the position of the director of the Princeton Radio Project. Merton was by 1940 already a renowned theorist. He had studied at Harvard University and his work there on the sociology and history of science earned him much deserved attention.

Lazarsfeld and Merton came from distinctly different scholarly backgrounds; the literature they drew on and the references in their bibliographies were very different and rarely overlapped [Merton 1998: 165]. Despite these deep differences, however, Lazarsfeld and Merton together established the Bureau of Applied Social Research (BASR), one of the leading institutions for social research after the Second World War. They coordinated their work, frequently complemented each other's input and output, and the outcome of their efforts served to enrich sociological theory.

While Lazarsfeld and Merton worked closely together for many years and jointly developed theory and methods, they wrote just several studies together. Lazarsfeld's biographer, David Sills, refers to only: ' . . . six published collaborative efforts ....' [Sills 1987: 270] In chronological order by date of origin these are: (1) a joint lecture by Merton and Lazarsfeld titled 'The Psychological Analysis of Propaganda' [Lazarsfeld and Merton 1944] and a slightly revised version of this published as a paper titled 'Studies in Radio and Film Propaganda' [Merton and Lazarsfeld (1943) 1968]; ${ }^{6}$ (2) a jointly authored theoretical and methodological article titled 'Mass Communication, Popular Taste and Organized Social Action' [Lazarsfeld and Merton 1948], which defined the significance and social functions of the mass media; (3) the co-edited book Continuities in Social Research: Studies in the Scope and Method of 'The American Soldier' [Lazarsfeld and Merton (1950) 1974], in which they described social science as a field that requires continuous interplay

importance of Lazarsfeld's work for contemporary social research methodology is discussed in Jeřábek and Soukup [2008].

${ }^{6}$ David Sills evidently counts both papers on propaganda as different texts, but they differ only in terms of the addition of two new paragraphs in the second paper [David Sills 1987: 270]. 
between theory and empirical research; (4) a proposal for the 'Advanced Training Centre in Social Research' [Lazarsfeld and Merton (1950) 1972)]; and finally, (5) the direct outcome of their collaboration in the field of theory and methodology 'Friendship as a Social Process' [Lazarsfeld and Merton 1954].7

The first decade of collaboration between the two took place in the field of communication research. They studied the influence of propaganda, the media, and personal communication on soldiers and civilians during the Second World War. For this purpose they devoted considerable attention to devising effective research tools. They also contributed to advancing a theory of mass communication and the analysis of the social functions of the mass media and both as a team and individually they enriched the theoretical repertoire of this field with two important concepts-'opinion leaders' and 'influentials'.

\section{Two combined research instruments: 'the programme analyser' and 'the focused interview'}

The collaboration between Merton and Lazarsfeld on empirical communication research provides an excellent example of the combined use of a measuring device and a group discussion. Paul Lazarsfeld and Frank Stanton invented an instrument for evaluating radio programmes called the 'programme analyser, ${ }^{8}$, while Merton developed a brand new type of method called the 'focused interview'.

How did the programme analyser work? Around ten people would meet in a room to evaluate continuous segments of a radio programme prepared for their listening and were asked, as Merton describes it, '. . . to press a red button on their chairs when anything they hear on the recorded radio program evokes a negative response-irritation, anger, disbelief, boredom - and to press a green button when they have a positive response' [Merton 1987: 552]. All the participants' responses were recorded by the machine as lines deviating upwards or downwards on an unfurling roll of paper. Once the whole programme had been played and evaluated, the research assistants removed the roll of paper from the device and counted the number of positive and negative evaluations based on the number of lines deviating in each direction [see Peterman 1940]. Data from these evaluative measurements were transcribed by hand onto a graph illustrating the course of the evaluations during the programme. ${ }^{9}$

7 I discuss publications (3), (4), and (5) in another paper which will be published in the book The Early Days of Survey Research and Their Importance Today by Braumüller Press [Hannes, Jerabek and Peterson forthcoming].

${ }^{8}$ Experiences working with the programme analyser in research have been described by Hollonquist and Suchman [1944].

9 A pair of histograms, delineated from the horizontal axis up and down, indicated the number of positive evaluations with lines pointing upwards and the number of negative evaluations with lines pointing downwards at each specific interval (e.g. every 15 or every 30 seconds; see Jeřábek [2006: 32-36]). 
Cooperation between Lazarsfeld and Merton grew out of their analysis of the programme analyser graphs. An anecdote recounted in Lazarsfeld's memoirs (and confirmed by Merton) describes the start of their collaboration along the following lines: During the first year that they both started work at Columbia University, Lazarsfeld, who at the time was living with his second wife, Herta Herzog, invited Robert and his wife to dinner. When they arrived, Lazarsfeld persuaded Merton to leave his wife in the company of Herta and come with him to the office of the Columbia Broacasting System to join him in conducting a lastminute test of a new radio programme for a Washington agency that later became the Office of War Information. Lazarsfeld and Merton left the dinner and went to the radio studio, where a group of respondents were in the process of evaluating the prepared radio programme. When the evaluation was finished, a moderator entered and began discussing the resulting graph with the participants in the experiment. Merton immediately began making useful critical comments about the moderator and passed them to Lazarsfeld on pieces of paper during the discussion. Lazarsfeld, pleased with Merton's active approach, asked him to watch another group, which was just entering the studio, and when they finished their evaluation he asked Merton if he would like to try out the role of moderator, conduct the interview with the respondents himself, and put his sharp observations to use. Merton accepted the invitiation and that de facto marked the beginning of their many years of cooperation [Merton 1987: 552-553; 1998: 167-168; Lazarsfeld 1975: 36]. ${ }^{10}$

During the war Merton worked on radio research not only with Lazarsfeld but also with Carl Hovland's team of scientists, who later published the third volume of the well-known American Soldier book [Hovland, Lumsdaine and Sheffield 1949]. They used the programme analyser to examine the impact of propaganda films. Merton himself described it as unplanned participation in what was for him an unfamiliar area of sociological research. His interest was sparked by the novelty of the task, and his professionalism led him to pursue the development of a new qualitative method [Merton 1998: 169]. Lazarsfeld's memoirs also described Merton's 'American Soldier' study, in which soldiers were screened a film selected on the basis of content analysis, and the programme analyser was used to observe their reactions to different parts of the film. The researchers then

${ }^{10}$ Lazarsfeld collaborated with Merton for 35 years since that first episode in the Department of Sociology at Columbia University and on a programme of empirical social research realised in the Bureau of Applied Social Research (BASR) at the university. Merton joined BASR and, according to Paul Neurath, in 1944 Lazarsfeld and Merton together came up with the institute's name. Merton suggested calling it the Bureau of Social Research; Lazarsfeld just added the precise and elegant 'Applied' to the name [Neurath 1978]. For the first several years Merton was Lazarsfeld's deputy, and later he went on to become the director of BASR [e.g. Lazarsfeld 1975: 36-43]. Merton noted: 'I did (reluctantly) serve as "Acting Director" whenever he, as Director, was off on a sabbatical or visiting professorship, or most consequentially, was engaged in establishing a European version of the Bureau.' [Merton 1998: 184] 
performed a qualitative analysis using specially prepared group interviews that Merton later systematised in the form of a new interviewing method, the 'focused interview'. Lazarsfeld called the detailed description of this methodological tool its 'codification' and credited Merton with its development [Lazarsfeld 1975: 49].

Merton and Patricia Kendall wrote an article introducing this method titled 'The Focused Interview', which was published in 1946 in Public Opinion Quarterly [Merton and Kendall (1946) 1955]. It was later republished in Lazarsfeld and Rosenberg's The Language of Social Research [Lazarsfeld and Rosenberg 1955: 476491]. A decade later, in 1956, Merton, Marjorie Fiske, and Patricia Kendall wrote the similarly titled handbook The Focused Interview-A Manual of Problems and Procedures [Merton, Fiske and Kendall 1956]. In it Merton and his two colleagues give a step-by-step description of the method and explain its main features, the necessary moderator skills, and the need to focus the listeners' attention on individual segments of a programme and to identify the positive and negative emotions tied to different segments of the programme and the reasons for the evaluations. Although it was Merton who developed the focused interview, he himself regarded it as the very first fruit of his collaboration with Lazarsfeld: '. . . There can be no doubt that the focused group interview represents an early outcome of Paul's and my collaboration ...' [Merton 1998: 169]. In 1975 Lazarsfeld predicted a promising future for the focused interview. He wrote: '. . . the technique of focused interview is not part of contemporary sociological literature. But it can be predicted that it will come into prominence again, as our profession is forced to pay increasing attention to evaluation' [Lazarsfeld 1975: 49; see, e.g., Jiří Remr 2008: 203-207].

What was so novel and important about this collaboration between Lazarsfeld and Merton? It was their combined application of the programme analyser and the focused interview repeatedly to the same research subjects. It was their joint development of a tool for measuring respondents' evaluations and of a qualitative device for obtaining a better understanding of the data provided by these evaluations. It was that it involved cooperation between an outstanding analyst on the one hand (Lazarsfeld) and a theorist (Merton) on the other, who, by combining their expertise and using the programme analyser and the focused interview, sought the best and most convincing explanations for the data obtained from both sources of information.

In a paper about focus groups and the focused interview, Merton [1987: 557] highlighted and praised the combined use of the programme analyser, content analysis, or controlled experiment on the one hand in order to produce quantitative measurements, and the focused interview on the other hand in order to obtain qualitative evaluations, hailing this approach as an advantage over the focus group method that was introduced subsequently and was rarely used in combination with measurement or experimental data. The strength of using the programme analyser and the focused interview together was that doing so meant 
combining a quantitative method with a qualitative method and thus combining measurement with understanding. And this methodological innovation, which was tested in research long before the widespread introduction of 'mixed methods', can be attributed to the collaboration between Lazarsfeld and Merton.

\section{'Studies in Radio and Film Propaganda'}

Lazarsfeld and Merton together published a study on propaganda [Lazarsfeld and Merton 1944] that originated as a joint paper written for a prestigious writers' congress in California in October 1943.11 They also wrote a revised version of that paper, which is the version that we will discuss here, and which I shall call the 'academic version'..$^{2}$ The differences between the two texts are small and relate mostly to stylistic edits, some altered terms (e.g. 'social science' instead of the original 'psychology'), and certain definitions, but one important addition to the revised, 'academic version' is that since it was intended for a wider audience it explains in detail what the programme analyser and the focused interview are and how such combined research is organised and technically set up.

The propaganda study can be read in two different ways. First, it is possible to concentrate on the purpose of the writers' congress and read the study as a 'congress paper', in which case we have to look at its patriotic content, the thrust of its argument being that 'the work of our "Bureau" is good for America's success in the war'. Second, the study can be read as an 'academic paper', in which case we have to concentrate on the model of scientific work presented in its analysis of propaganda. Both aspects are present in both versions of this study that were eventually published. The 'congress reading' of the study is how it would have been heard or read in the context of the war. But read outside the context of the war, and with the definitions and methodological description added, we get an 'academic reading'. Below when I discuss the first aspect, I will speak about the 'congress reading' and when I analyse the scientific aspect, I will use the label 'academic reading'

The first version of the paper was presented at a very patriotic event. The writers' congress was held in the midst of the war and was sponsored by the Hollywood Writers' Mobilization Commitee and the University of California. The congress opened with the reading of a greeting letter from President Roosevelt, who highlighted the importance of engaged writers 'in these times', and

\footnotetext{
${ }^{11}$ It was presented under the title PFL \& RKM: 'The Psychological Analysis of Propaganda.'

12 The second version of the text, following obvious authors' revisions, bore the somewhat more general title 'Studies in Radio and Film Propaganda' and was published in the journal Transactions of the NY Academy of Sciences, Vol. 6, No. 2, Nov. 22 1943, in November 1943, and Merton later included it as a chapter in his book Social Theory and Social Structure [Merton and Lazarsfeld (1943) 1968].
} 
so as to leave no doubt about what their role was he stated: 'Already, the men and women gathered there have rendered great service in elucidating for the nation the issues of this war and the nature of our enemies.' [Roosevelt 1944: x] Lazarsfeld and Merton's original paper needs to be viewed in this context, as although it was scientific in content, it was patriotic in style and arguments, and was presented on the last day of the congress at a discussion panel devoted to the theme of propaganda. ${ }^{13}$

In their 'congress paper' Lazarsfeld and Merton set out to present propaganda as an effective tool for influencing soldiers and civilians during wartime (in a democratic society - they were talking about America) [Lazarsfeld and Merton 1944]. The nature of BASR's work was such that it was naturally drawn into involvement in the preparation of radio programmes and films designed to boost the public's war morale and efficiently and effectively inform and influence civilians about the war, about the needs of the country, and about the duties of civilians. How seriously BASR took this role is apparent from the papers in the yearbook Radio Research 1942-1943, which Lazarsfeld edited with Frank Stanton during the war [Lazarsfeld and Stanton 1944]. ${ }^{14}$

Merton became involved on more than just a symbolic level in the academic community's 'practical war effort' through the research he conducted on the sale of war bonds, described in the study 'Mass Persuasion' [Merton, Fiske and Curtis 1946], and by drawing on his experience working with Carl Hovland's research team testing films for soldiers and civilians (later published as the third volume of American Soldier) [Hovland, Lumsdaine and Sheffield 1949]. These films, as well as various programmes aired by American radio broadcasters, were intended to boost the morale of soldiers and civilians and protect them against counterpropaganda. However, the issue that Lazarsfeld and Merton focused on in their congress paper was the need to eliminate errors from these 'propaganda tools', as they could become a source of misunderstanding or even produce an effect opposite to that intended by the film's authors. Merton and Lazarsfeld, as representatives of a major US research institution, shared and expressed the patriotism that was felt across America at this time. The direction and (often joint) results of the work they did during the Second World War, as well as the content of the 'congress version' of their propaganda study, clearly indicate that there was a practical purpose to their research during this period, namely, helping the United States' progress in the war effort.

\footnotetext{
${ }^{13}$ In one note in his article 'Working with Merton' Lazarsfeld frankly stresses Merton's authorship of the paper: 'At one point during the work for the army Merton wrote a paper "Studies in Radio and Film Propaganda", for which he gave me joint credit (STS 1947, Chap. 10). Note 52 [Lazarsfeld 1975: 65].

${ }^{14}$ It published studies on German propaganda [Kris and White 1944; Speier and Otis 1944] and on effective methods of communicating information to the population of the United States during the war [Siepmann 1944].
} 
The 'academic version' of the study opens with a definion of propaganda as: '. . . any and all sets of symbols which influence opinion, belief or action on issues regarded by the community as controversial' [Merton and Lazarsfeld (1943) 1968: 563]. They expressed their 'academic' perspective with the statement: 'In our view, propaganda has no necessary relation to truth or falsity.' [ibid.: 563] They report on some studies conducted in the Second World War and described the findings and conclusions produced by the research carried out by BASR [Merton and Lazarsfeld (1943) 1968: 564]. Roughly equally they discuss the research methods that must be used to achieve such results.

The 'academic version' is divided into four sections: three focus more on methodology (as indicated by their titles: modes of propaganda analysis, content-analysis, response-analysis), and one, the final section, contains general conclusions (technological propaganda or the propaganda of facts). Merton's 'theorising' and Lazasfeld's 'attention to detail' are evident in all four sections. Merton brought to the paper his personal experience with empirical research from the studies testing 'war films'. Notes on issues like 'unexpected responses' and the 'boomerang effects' of propaganda messages are likely Merton's contributions, while comments on 'the errors of the propagandist' and lists of specific 'types of content-analysis' probably come from Lazarsfeld [Merton and Lazarsfeld (1943) 1968: 568-569]. In the introductory paragraph Merton and Lazarsfeld break down their task into two sets of questions, the first set is answered using 'content analysis' and answers to the second group are provided through 'response analysis'. This section of the paper closes with a statement about the clearly didactic intentions of the subsequent discussion of the analysis of propaganda, its results, and the methods used to attain them: 'Perhaps by focusing on problems actually encountered in these studies, we can make clear some of the procedures of content- and response-analysis which have been developed.' [Merton and Lazarsfeld (1943) 1968: 566]

The content analysis revealed a weakness found in most propaganda programmes relating to the war, which was that to a greater or lesser degree they relied on stereotypical personifications of the enemy (the Axis) and the Allies. The programmes portrayed the enemy through symbols like Hitler, Mussolini, and Goering, consequently depicting the enemy as 'a small band of evil men', which generated the impression amongst viewers that all would be well once those men were destroyed [Merton and Lazarsfeld (1943) 1968: 567]. Conversely, the other 'actors in the battle', the United States and the 'United Nations' (the reference used to describe the Allied forces in the fight against the Berlin-RomeTokyo 'Axis') are not given equal or similar degrees of personification, resulting in a simplified understanding of the situation and confusing viewers. ${ }^{15}$

\footnotetext{
${ }^{15}$ If the contemporary mass media and actors of state propaganda had carried out a similar content analysis similar conclusions on shaping public opinion could have been reached. This 'small band of evil men' are presented daily in the mass media even today, and citizens are constantly surprised that 'once these men are destroyed, all is still not well'.
} 
The method of content analysis also helped reveal a problem that arises when two themes are presented in different ways: one theme is presented mainly in the text, the other almost exclusively in the visual material. Readers who mainly notice visual aspects do not notice the first theme, and the whole intended meaning is distorted and misses its mark. The authors pointed out that the main purpose of content analysis is '. . . to provide clues to probable responses to the propaganda' [Merton and Lazarsfeld (1943) 1968: 570].

This finding, while interesting, was not enough for Merton and Lazarsfeld, who insisted that any results produced through content analysis must also be tested by conducting interviews with members of the audiences. They proceeded to conduct a 'special type of interview' called the 'focused interview' [ibid.: 570].

The 'academic version' of the propaganda study explains the purpose, objectives, and method of conducting the focused interview. In it the respondent is not supposed to assume the role of a professional critic or consultant on the given material or programme analysed. Instead, the interview focuses on aspects of the programme that are significant for the respondent. It should illuminate what impression the film, radio programme, or print material left in the respondent's mind [ibid.: 570]. In the paper, Merton and Lazarsfeld outline the principles involved in conducting a focused interview and cite examples of unexpected effects of propaganda, describing four in which people responded to propaganda in a manner opposite to that intended by the author; they called this the 'boomerang effect'.

The paper also contains passages on methodology that one would not normally expect in this type of text and includes some statements that I would even call groundbreaking. For instance, there is a remarkably significant statement on the combined use of quantitative and qualitative methods: '. . . the focused interview enables us to supplement and enrich the value of the traditional controlled experiment ...' [Merton and Lazarsfeld (1943) 1968: 575]. In their analysis of the 'boomerang effect' Merton and Lazarsfeld discovered that the effect of a propaganda film on an experimental group failed to achieve the planned response when the film presented viewers with two themes: (1) the 'immense cruelty and sadism of the Nazis' and (2) 'their threat to our way of life exemplified by scenes of mistreatment of civilians simply because of their political or religious convictions', each of which was effective. It consequently produced responses which canceled each other out [ibid.: 575]. The experiment showed that the joint effect of two factors (i.e. 'the net result') on the resulting 'willingness of the respondents to support American intervention in the war ... may be nil'.

Here, Merton's focused interview is essential because it provides explanations for the viewers' reactions, which are not (nor could be) revealed just from the results of the experiment. The focused interview proved instrumental in uncovering the source of the unwillingness respondents expressed after viewing the film to support the United States' entry into the war. The reason for that was their ' . . . fears and anxieties from the Nazi army, exemplified . . . by detailed and 
vivid sequences of Nazi fighting men in action'. And although 'the Nazi-cruelty theme elicited agression in the attitudes of Americans', the effects of these two impulses cancelled each other out [Merton and Lazarsfeld (1943) 1968: 574-575]. The willingness of the respondents to support American intervention in the war because of the Nazis' cruelty contradicted the unwillingness of the same experimental group to support the Americans' entry into the war because they were afraid of civilian mistreatment (as witnessed in the film) and were frightened by the images of Nazi soldiers in action. This discovery is the joint result of both Lazarsfeld and Merton: a co-product of Merton's focused interview method and field work experience and Lazarsfeld's methodological explanations.

\section{‘Mass Communication, Popular Taste and Organised Social Action'}

The next paper that Merton and Lazarsfeld worked on together was one of enormous theoretical importance and since its first publication it has been republished many times. Elihu Katz and his collegues included it among the Canonic Texts in Media Research [Katz et al. 2003], and its canonic status was confirmed in a study by Peter Simonson and Gabriel Weimann [2003]. Most of the observations about the communication process that are made in the remarkable article 'Mass Communication, Popular Taste and Organised Social Action' [Lazarsfeld and Merton (1948) 1971] are still valid today. The paper addresses three themes: the potential power of the mass media, the conformism of the enormous audiences of the mass media, and the low level of aesthetic and cultural tastes of the public influenced by the mass media. This conforms to Merton's theory of the 'latent' or 'unthinking' function of media. The third effect mentioned by Paul Lazarsfeld and Robert K. Merton more precisely means the fear of and fact that: '. . . these technically advanced instruments of mass communication constitute a major avenue for the deterioration of esthetic tastes and popular cultural standards' [Lazarsfeld and Merton (1948) 1971: 458].

The paper opens with an analysis of the social functions of the mass media. The expectations behind Lazarsfeld's Princeton Radio Project, which was launched in the late 1930s and continued at Columbia University's Bureau of Applied Social Research in the early 1940s, were that radio and other new mass media could bring education to the public. These expectations in principle proved false. Despite this partial failure, however, at the time the article was written, in 1948, shortly after the end of the war, the mass media were already fulfilling and still fulfil many other important social functions [Lazarsfeld and Merton (1948) 1971: 460].

Merton and Lazarsfeld identified three social functions of mass media: (1) the status-conferral function: the media direct attention to and legitimise the status of individuals and groups, and they show how important a person, event or issue is; (2) the enforcement of social norms: how the mechanism of public 
exposure operates and why it is so important-'In a mass society, this function of public exposure is institutionalized in the mass media of communication. Press, radio and journals expose fairly well known deviations to public view, and as a rule, this exposure forces some degree of public action against what has been privately tolerated' [Lazarsfeld and Merton (1948) 1971: 462-463]; and (3) the narcotising dysfunction of the mass media: exposure to a flood of information usually serves to narcotise rather than energise the average reader or listener-'As an increasing amount of time is devoted to reading and listening, a decreasing share is available for organized action.' [Lazarsfeld and Merton (1948) 1971: 464] The authors claimed that mass communication could be transformed into one of the most respectable and efficient of social narcotics.

In this article Lazarsfeld and Merton also formulated the rules for effective propaganda, referring to three specific conditions, at least one of which must be satisfied if the propaganda is to be effective: (1) the mass media's monopolisation occurs in the absence of counterpropaganda; (2) behaviour or attitudes are canalised rather than basic values being changed; and (3) supplementary face-to-face contact is made.

Merton took an example of monopolisation from his study on the 'war bond drive' [Merton, Fiske and Curtis 1946]. This study involved an in-depth analysis of the motives, arguments, and style of the very effective and persuasive campaign conducted by a popular radio star named Kate Smith during the Second World War [cf. Jerabek forthcoming]. Kate Smith's radio appeals broadcast in 1943 influenced many thousands of Americans, who over the course of one day and one night bought 39 million US dollars worth of war bonds. Here Merton pointed out that the public images of the moderator of the war bond drive were monopolistic in that they occurred in isolation, with no counterpropaganda to challenge her influence. He writes: ' . . . the public images of Kate Smith are at no point subject to a counterpropaganda. ... an unmarried radio entertainer with an annual income in six figures may be visualized by millions of American women as a hard-working mother who knows the recipe for managing life on fifteen hundred a year' [Lazarsfeld and Merton (1948) 1971: 470; cf. Merton, Fiske and Curtis 1946].

Advertising is a good example of canalisation. It is much easier to canalise pre-existing behaviour patterns or attitudes in one direction or another than it is to seek to instill new attitudes or to create significantly new behaviour patterns [cf. Lazarsfeld and Merton (1948) 1971: 470]. Finally, Lazarsfeld's extensive experience with work on 'opinion leaders' and Merton's with work on 'influentials' provided them with examples for explaining the importance of face-to-face contact in mass persuasion and propaganda.This collaborative piece of work by Merton and Lazarsfeld shows how naturally they built their specific form of collaboration on communication theory out of many elements in their respective research projects. 


\section{‘Opinion leaders' and 'influentials' - two kindred concepts}

Lazarsfeld and Merton developed and conceptualised two 'kindred' concepts that both address the issue of how some people (called 'opinion leaders' or 'influentials') influence the opinions of other people around them in the course of interpersonal communication. Below we will examine each of the studies behind the development of these two concepts and their findings on the influence of special actors in society and we will identify what the kindred concepts have in common and how they differ.

\section{Paul Lazarsfeld's 'opinion leaders'}

In 1940 Lazarsfeld conducted a study with Bernard Berelson and Hazel Gaudet on the formation of voter opinions during pre-election campaigns. The three researchers published their findings four years later in the classic monograph ${ }^{16}$ The People's Choice. How the Voter Makes Up His Mind in a Presidential Campaign [Lazarsfeld, Berelson and Gaudet 1944]. The study identified and gave the first ever description of the role that socially active people occupy in influencing the opinions of others in their immediate surroundings. The study referred to these people as 'opinion leaders' and they were described as those people to whom others, in the same immediate surroundings, turn for their opinions or who in interpersonal communication offer their opinion preferences on a given subject or field to others in their immediate surroundings [Lazarsfeld, Berelson and Gaudet 1944: 49-51].

The study was originally designed to test some hypotheses on the effects of the mass media on voter preferences. However, the study was conceptualised in such a way that the researchers were also able to discover a number of other factors that play a role in voter decisions. The research design of the study and its organisation as a panel survey was instrumental in attaining these findings. Over the course of seven rounds of interviews with the same respondents at monthly intervals Lazarsfeld and his colleagues devised a research design that examined both the effects of the media and interpersonal communication.

In each round of interviews the respondents were asked about their voter preferences and any preference changes. Every change in opinion confirmed by the respondent was subject to a battery of questions on the circumstances surrounding it. Most of the questions focused on observations relating to the mass media and the election campaign. But other questions looked at the wider context that could have influenced the minds and decisions of voters. Lazarsfeld and his colleagues asked respondents not only why they had changed their opinion but also under what circumstances they had changed it.

${ }^{16}$ A detailed description and interpretation of the methodology and findings of The People's Choice study can be found in Jeřábek [2006: 90-112]. 
Paul Lazarsfeld and his colleagues also posed questions that eventually helped them to identify and codify opinion leaders. They asked their respondents two questions, which were then used to distinguish which respondents identified themselves as persons whose opinions influence their social surroundings, i.e. as opinion leaders. This classic pair of questions was worded as follows: (1) 'Have you tried to convince anyone of your political ideas recently?'; (2) 'Has anyone asked your advice on a political question recently?' [Lazarsfeld, Berelson and Gaudet 1944: 50]

In the original study, Lazarsfeld and his colleagues picked out all the respondents who answered one or both questions in the affirmative as opinion leaders. They then proceeded to show that opinion leaders display a greater interest in the news presented through the media, more often and to a greater degree communicate face to face with people around them, and formulate opinions more quickly. It is thus easier for them to influence the opinions of other people with whom they are naturally in contact. Lazarsfeld labelled those people whose views are influenced by opinion leaders as 'opinion followers'.

In this study Lazarsfeld also questioned the 'silver bullet theory' that had dominated the field of communication theory to that time, which assumed that the mass media have a direct and equivalent effect on all the recipients of the communication. Here he first articulated his hypothesis of the two-step flow of communication, according to which information from the mass media spreads in two phases: first from the media to opinion leaders, and then from those people through interpersonal communication to their opinion followers.

Lazarsfeld expressed the now classic hypothesis of the two-step flow of communication as follows: '. . . ideas often flow from the radio and the press to opinion leaders and from them on to the less active parts of the population' [Lazarsfeld, Berelson and Gaudet 1944: 151]. This personal influence of opinion leaders could even involve simply drawing attention to an important speech broadcast on the radio or an interesting article in the newspaper. Opinion leaders represented a kind of bridge between the formal media and persons less interested in the media. The researchers noted five significant psychological features of interpersonal communication [Lazarsfeld, Berelson and Gaudet 1944: 152-157] that make it a particularly effective source of persuasion during a pre-election campaign and which in the end lead to the political homogeneity of social groups:

1. 'Given that most interpersonal communication on political issues is not planned and occurs only along the edges of casual conversation, the speaker is not suspected of deliberate propaganda on behalf of a particular party. By means of interpersonal communication it is therefore possible to address a person who is not interested in politics and who does not follow it in either the radio or the newspapers.' [Lazarsfeld, Berelson and Gaudet 1944: 152-157]

2. 'If a person encounters opposition in interpersonal communication they can react to it in direct contact and accommodate their argumentation to it; or they can stop it, change the subject of discussion, and return to it later from a 
different perspective. The main advantage of interpersonal communication in comparison with other means of communication is face-to-face conversation and the possibility of reacting directly and flexibly.' [ibid.]

3. 'The opportunity to offer something in return for a positive response to a personal recommendation is an advantage of interpersonal communication. All means of symbolic interpersonal communication can be employed to express an agreement or, conversely, a negative reaction to opposition. Rewarding someone for compliance is a taught reaction, tested out even in childhood, and as an established form of behaviour people are much more likely to use it spontaneously.' [ibid.]

4. 'In interpersonal communication the source of the recommendation and arguments benefits from an additional element of trust. A respected person in personal contact is a much more trustworthy source of information and arguments than the impersonal formal media.' [ibid.]

5. 'The behaviour of a person who is trusted is often copied without the exact motivations behind the decision for such behaviour being sought. The voter simply follows someone they trust, who leads them to vote through interpersonal communication.' [ibid.]

The general findings that Lazarsfeld, Berelson and Gaudet reached in the study were also confirmed in further studies. ${ }^{17}$ Paul Lazarsfeld and Elihu Katz devoted another research project to researching opinion leaders (this time women leaders and women followers), which resulted in the book Personal Influence. The Role People Play in the Course of Mass Communication [Katz and Lazarsfeld 1955]. This study looked at four selected areas of a woman's life-fashion, going to the movies, shopping, and public issues. In this study the researchers turned their attention to testing their hypotheses about the two-step flow of communication and confirming the interactions between opinion leaders and opinion followers.

\section{Merton's 'influentials'}

Lazarsfeld argued that the ability of one person to convince another person in direct interpersonal communication is greater than any and all methods of mass communication. This view of his about the significance of 'personal influence' for the formation of people's attitudes was shared by Merton, whose study, 'Patterns of Influence: A Study of Interpersonal Influence and of Communications Behavior in a Local Community', introduced the new concept of 'the influential', in the place of the concept of the 'opinion leader', to explain interpersonal influence [Merton 1949]. Merton's study, based on research conducted in the autumn

${ }^{17}$ Elihu Katz published a concise analysis of the results of 'The People's Choice' study and of four follow-up studies in a famous review article in Public Opinion Quarterly [Katz 1957]. 
of 1943, was published in 1949 in a volume of studies on communication research [Lazarsfeld and Stanton 1949]. Merton's careful analysis was the source of his later famous typology of 'locals' and 'cosmopolitans'. Originally this study was a typical communications research assignment of the kind Lazarsfeld's team were often commissioned to perform. The client in this case was Time magazine, which sought to corroborate the results of an earlier, 1940 study done by Lazarsfeld, Berelson and Gaudet [1944], which found that the magazine was read mainly by opinion leaders in small towns: 'So Time magazine commissioned a follow up study in Dover, New Jersey.' [Lazarsfeld 1975: 51] This task was assigned to Merton and he embraced it with academic penetration. This study became the source of a theoretically ground-breaking paper in which Merton presented one of the most important and best substantiated typologies of influentials or opinion leaders.

In his typology of 'influentials' Merton adopted a slightly different perspective than that of Lazarsfeld's 'opinion leaders'. In a letter to the author of this article, in response to a direct question about the relationship between the two concepts, Merton wrote:

The 'Patterns of Influence' study was in effect an extension and differentiation of PFL's earlier studies of 'opinion leaders'. You ask whether PFL and I 'sometimes discussed' the concepts of 'influentials' and 'opinion leaders'. Indeed, we did. In those discussions, I tried to make the case that the sample of run-of-themine people in Rovere hardly included 'opinion leaders' in any reasonable sense of that category; they were simply exerting influence, often unwittingly, on others in their social networks. Hence, they were 'influentials', not 'opinion leaders'. Moreover, it eventually became clear to me that the grounds of their influence varied significantly and that this required a differentiation of types of influentials: locals and cosmopolitans. ${ }^{18}$

Merton rejected a superficial typology based on the idea of 'currently influential', 'potentially influential', 'waning influential', and 'dormant influential' as 'sterile' [Merton 1949: 185-186]. The one-dimensionality of this typological distribution would not allow researchers to account for the influentials' diverse behaviours. He replaced the term 'opinion leader' with the related term 'influential' and, although Merton used the 'standard procedure of interviewing first a random sample and then the people who had been named as influentials' [Lazarsfeld 1975: 51], he reached conclusions that differed from the kind of findings other members of Lazarsfeld's team were coming up with-his findings were closer to sociological theory. Lazarsfeld wrote that Merton used 'classical sociological categories to material collected in a different world' [Lazarsfeld 1975: 51] and 'looked at these influentials as agregates of concrete actors pursuing a variaty of goals' [ibid.]. He outlined the strucure of two types of influentials in a town: 'locals' and 'cosmopolitans'.

${ }^{18}$ R. K. Merton, letter to the author, 17 December 1995. 
It was Merton's interest in identifying these two types of influentials that differentiated his findings from Lazarsfeld's findings, which were based on the use of the two-step flow of communication and its application to all opinion leaders and their behaviour. Merton was interested in the distinct routes by which these two types of influentials reached the position of 'influential person' in the community and especially what different models of communication behaviour they conformed to as result of the different goals of locals and cosmopolitans in the community.

In his study Merton referred to the town of Dover as Rovere (which also exists), probably for ethical reasons. He began his study by approaching 86 informers in the town and asked them to name local inhabitants who could be described as influencing the opinions of their co-inhabitants in various areas of life. This gave him a list of 379 individuals drawn from 1043 individual recommendations, some of which overlapped. Only 57 of the town's citizens were named four or more times. Merton designated these people as 'influentials'. He then conducted in-depth interviews with them and examined their communication methods. These in-depth interviews and accompanying observations formed the basis of Merton's analysis and typology of 'local' and 'cosmopolitan' influentials.

Merton highlighted the differences beween these two types of influentials through two open, de facto projective, questions. The first question was concerned with the effect of the war on the economic situation in Rovere, and the second asked respondents: 'Do you worry much about the news?' In the autumn of 1943 news understandably meant news from the war. One group of responses concentrated on the problems of national security and international order, stability in the post-war world, the formation of international organisations, and attaining peace. The second block of responses related to the problems the war caused for people in the town. Merton called the respondents who gave the first type of answers 'cosmopolitan influentials' and the second type 'local influentials' [Merton 1949: 190].

Local and cosmopolitan influentials differ in a number of ways: by the structure of their social ties; the paths that led them to their current position in the influence structure; the ways they used their position to exercise personal influence; and methods of communication behaviour [Merton 1949: 191]. Most local influentials were long-time residents and local patriots, and they had many friends and acquaintances in the town. They were usually unable to imagine living anywhere else. Most cosmopolitan influentials had moved to Rovere from somewhere else and were able to imagine living elsewhere [Merton 1949: 191-192]. Local influentials liked to be in frequent contact with many people. Conversely, cosmopolitan influentials preferred to 'exchange opinions' with friends that they 'could really talk to' [Merton 1949: 193-194]. Both groups of influentials were members of numerous associations. However, they were inclined towards different types of organisations. 'Locals' clearly favoured clubs that were primarily oriented towards 'making contacts' and 'forming personal ties'. 'Cosmopolitans' sought out profes- 
sional associations and 'hobbyist' clubs [Merton 1949: 196]. For local influentials, personal ties were both the outcome and instrument of their particular influence. For cosmpolitan influentials, personal ties were usually just the outcome but not an instrument of their influence [Merton 1949: 198]. 'Locals' and 'cosmpolitans' are looked to and respected as influentials for different reasons. Cosmopolitan influentials are respected because they know, local influentials because they understand [Merton 1949: 201].

The different characteristics of local and cosmopolitan influentials are the source of their different 'communication behaviour'. In this respect Merton's concept went beyond Lazarsfeld's model of opinion leaders in that it no longer postulated different versions of communication behaviour. His concept is thus theoretically richer. Nevertheless, literature in subsequent decades made reference to the concepts and advanced both lines of the thought [see, e.g., Weimann 1994].

The second and no less important link between the studies by Merton and those by Lazarsfeld is Merton's proposed classification of spheres of influence. He distinguished influentials as excercising either a monomorphic or a polymorphic influence. A monomorphic influential is sought out for advice in one area of life, while a polymorphic influential is a universal advisor. In Personal Influence Lazarsfeld and Katz also distinguished between two types of opinion leaders 'universal influential' and 'specific influentials' [Katz and Lazarsfeld 1955: 140-143].

Merton further pursued this line of research. In a letter to the author of this article [Merton 1995] he referred to two papers by A. Gouldner, who had studied both types of influentials in two articles he published in Administrative Science Quarterly [Gouldner 1957, 1958], and to Rosabeth Moss Kanter's book World Class [1995], which powerfully extends Merton's idea by combining the strength of local ties with the significance of their global utilisation [Merton 1995].

Contemporary applications of Lazarsfeld's and Merton's ideas are found in the work of John Black [1982], Marc Granovetter [1973], Elisabeth Noelle-Neumann [1983, 1985], and Gabriel Weimann [1991, 1994]. Noelle-Neumann drew on the concepts of opinion leaders and influentials to develop the 'personality strength scale' (PS-scale) as a continuous scale for measuring 'opinion leadership' or 'personal influence' [Noelle-Neumann 1983, 1985; Noelle-Neumann and Csikszentmihalyi 1992]. Gabriel Weimann used the PS-scale in his research in Israel and presented it to English-speaking sociologists [Weimann 1991, 1994]. I have analysed all these works in a number of publications [Jeřábek 2003, 2008] and have applied the PS-scale to three different surveys in the Czech Republic.

\section{Conclusion}

The cooperation between Lazarsfeld and Merton on communication research produced significant theoretical and methodological advances. It was one of the most important research areas that they worked on together and they attained remarkable results. First, they pioneeringly introduced the idea of making com- 
bined use of all available research methods, i.e mixing quantitative and qualitive methods to obtain data and understanding. So they used Merton's 'focused interview' with Lazarsfeld and Stanton's programme analyser and/or with content analysis.

They put sociology to practical use by applying research in the service of the US war effort. Their joint study on propaganda reflects this objective. They achieved it through Lazarsfeld's studies of the effects of radio broadcasts during the war and Merton's detailed study of films designed to boost the morale of soldiers and civilians during the war. They again found practical application for sociological theory in their interesting conceptualisations of the social functions of mass media. Lazarsfeld's contribution to the analysis and Merton's contribution to the theoretical part of the study resulted in the joint conclusions on the role and possible uses or abuses of the mass media in society. The enduring relevance of their analytical and theoretical results is apparent in that their findings to some extent still apply to the current role and function of the mass media in our society.

Finally, Merton and Lazarafeld developed, substantiated, and advanced a pair of related concepts for use in analysing interpersonal communication: 'opinion leaders' and 'influentials'. Lazarsfeld put forth the hypothesis of the two-step flow of communication and Merton formulated a typology of 'local and cosmopolitan influentials'. Both concepts are still vital, applied, and built on. In this sense they thus also singificantly contributed to communication research. But it was their collaboration, the complementary interaction between a sociological theorist and a methodologist and empiricist, that was crucial to the advances they were able to make in the field of social research.

HyneK JeRABeK is a professor of sociology at the Faculty of Social Sciences of Charles University in Prague. He is the author of numerous works about sociological methodology, including Paul Lazarsfeld's Research Methodology. Biography. Methods. Famous Projects, Prague, Carolinum 2006. He is the leader of the project 'Classic Research Projects as a Source of Inspiration for Contemporary Social Research', in which he focuses on the history of empirical social research.

\section{References}

Black, J. S. 1982. ‘Opinion Leaders: Is Anyone Following?' Public Opinion Quarterly 46: 169 -176 .

Crothers, C. 1998. 'The Relation between the Logics of Merton's Theory and Lazarsfeld's Methodology: Their Intellectual Compatibility and Research Partnership.' Pp. 213-253 in Paul Lazarsfeld (1901-1976) La sociologie de Vienne à New York, edited by J. Lautman and B. P. Lécuyer. Paris and Montréal: L’Harmattan. 
Gitlin, T. 1978. 'Media Sociology: The Dominant Paradigm.' Theory and Society 6: 205-253.

Gouldner, A. W. 1957. 'Cosmopolitans and Locals: Toward an Analysis of Latent Social Roles-I' Administrative Science Quarterly 2: 444-480.

Gouldner, A. W. 1958. 'Cosmopolitans and Locals: Toward an Analysis of Latent Social Roles-II' Administrative Science Quarterly 2: 281-306.

Granovetter, M. S. 1973. 'The Strength of Weak Ties.' American Journal of Sociology 78: $1360-1380$.

Hall, S. 1982. 'The Rediscovery of "Ideology": Return of the Repressed in Media Studies.' Pp. 56-90 in Culture, Society, and the Media, edited by M. Gurevitch, T. Bennett, J. Curran, J. Woollacott. London: Methuen.

Hollonquist, T. and E. A. Suchman. 1944. 'Listening to the Listener. Experiences with the Lazarsfeld-Stanton Programme Analyser.' Pp. 265-334 in Radio Research 1942-1943, edited by P. F. Lazarsfeld and F. N. Stanton. New York: Duell, Sloan and Pearce.

Hovland, C., A. A. Lumsdaine and F. D. Sheffield. 1949. Studies in Social Psychology in World War II., Vol.3: Experiments in Mass Communication. Princeton, NJ: Princeton University Press.

Jeřábek, H. 1997. Paul Lazarsfeld a počátky komunikačního výzkumu. (Paul Lazarsfeld and the Beginnings of Communication Research), Prague: Karlova Univerzita.

Jeřábek, H. 2003. 'Měření názorového vůdcovství v českých sociologických výzkumech. PS škála jako nástroj pro zjištování názorového vůdcovství.' (Measuring Opinion Leadership in Czech Sociological Research: Personality Strength Scale as a Tool for Opinion Leadership Identification) Sociologický časopis/Czech Sociological Review 39 (5): 487-506.

Jeřábek, H. 2006. Paul Lazarsfeld's Research Methodology. (Biography, Methods, Famous Projects). Prague: Karolinum.

Jeřábek, H. 2008. 'Repeated Measurements of Opinion Leadership in the Czech Republic-The Personality-Strength Scale.' Pp. 199-220 in Advanced Lazarsfeldian Methodology, edited by H. Jeřábek and P. Soukup. Prague: Karolinum.

Jeřábek, H. forthcoming. 'Six Examples of Collaboration between Robert K. Merton and Paul F. Lazarsfeld.' In The Early Days of Survey Research and Their Importance Today, edited by H. Haas, H. Jeřábek and T. Petersen. Vienna: Braumüller Press.

Jeřábek, H. and P. Soukup (eds.). 2008. Advanced Lazarsfeldian Methodology. Prague: Karolinum.

Kanter, Rosabeth, Moss. 1995. World Class: Thriving Locally in the Global Economy. New York: Touchstone.

Katz, E. 1957. 'The Two-Step Flow of Communication: An Up-To-Date Report on a Hypothesis.' Public Opinion Quarterly 1: 61-78.

Katz, E. and P. F. Lazarsfeld. 1955. Personal Influence. The Part Played by People in the Flow of Mass Communications. Glencoe, IL: The Free Press.

Katz, E., J. D. Peters, T. Liebes and A. Orloff. 2003. Canonic Texts in Media Research: Are There Any? Should There Be? How About These? Oxford: Polity Press and Blackwell Publishers.

Kris, E. and H. White. 1944. 'The German Radio Home News in Wartime.' Pp. 181-208 in Radio Research 1942-1943, edited by P. F. Lazarsfeld and F. N. Stanton. New York: Duell, Sloan and Pearce.

Lazarsfeld, P. F. 1975. 'Working with Merton.' Pp. 35-66 in The Idea of Social Structure. Papers in Honor of Robert K. Merton, edited by L. A. Coser. New York: Harcourt Brace Jovanovich.

Lazarsfeld, P. F., B. R. Berelson and H. Gaudet. 1944. The People's Choice. How the Voter Makes Up His Mind in a Presidential Campaign. New York: Duel, Sloan and Pearce. 
Lazarsfeld, P. F. and R. K. Merton. 1944. 'The Psychological Analysis of Propaganda.' Pp. 362-380 in Writers' Congress. The Proceedings of the Conference held in October 1943 under the sponsorhip of the Hollywood Writers' Mobilization and the University of California. Berkeley and Los Angeles, CA: University of California Press.

Lazarsfeld, P. F. and R. K. Merton. 1954. 'Friendship as Social Process: A Substantive and Methodological Analysis.' Pp. 18-66 in Freedom and Control in Modern Society, edited by M. Berger, T. Abel and C. Page. New York: D. van Nostrand.

Lazarsfeld, P. F. and R. K. Merton. [1948] 1971. 'Mass Communication, Popular Taste, and Organized Social Action.' Pp. 554-578 in The Process and Effects of Mass Communication, edited by W. Schramm and D. F. Roberts. Urbana and Chicago, IL: University of Illinois Press.

Lazarsfeld, P. F. and R. K. Merton. [1950] 1972. 'Professional School for Training in Social Research.' Pp. 361-391 in Qualitative Analysis. Historical and Critical Essays. Boston, MA: Allyn and Bacon Inc.

Lazarsfeld, P. F. and R. K. Merton (eds.). [1950] 1974. Continuities in Social Research: Studies in the Scope and Method of 'The American Soldier'. New York: Arno Press.

Lazarsfeld, P. F. and M. Rosenberg (eds.). 1955. The Language of Social Research. A Reader in the Methodology of Social Research. New York: The Free Press.

Lazarsfeld, P. F. and F. N. Stanton (eds.). 1944. Radio Research 1942-1943. New York: Duell, Sloan and Pearce.

Lazarsfeld, P. F. and F. N. Stanton (eds.). 1949. Communications Research 1948-1949. New York: Harper \& Brothers.

Lombardo, C. 2004. 'Lazarsfeld, Merton e la scuola sociologica della Columbia.' Sociologia e ricerca sociale $74: 127-149$.

Merton, R. K. 1949. ‘Patterns of Influence: A Study of Interpersonal Influence and of Commnunications Behavior in a Local Community.' Pp. 180-210 in Communications Research 1948-1949, edited by P. F. Lazarsfeld and F. N. Stanton: New York: Harper \& Brothers.

Merton, R. K. 1987. 'The Focused Interview and Focus Groups. Continuities and Discontinuities.' Public Opinion Quarterly 51: 550-566.

Merton, R. K. 1998. 'Working with Lazarsfeld.' Pp. 163-211 in Paul Lazarsfeld (1901-1976) La sociologie de Vienne à New York, edited by J. Lautman and B. P. Lécuyer. Paris, Montréal: L'Harmattan.

Merton, R. K., M. Fiske and A. Curtis. [1946] 1971. Mass Persuasion. The Social Psychology of a War Bond Drive. Westport, CT: Greenwood Press Publishers.

Merton, R. K., M. Fiske and P. L. Kendall. 1956. The Focused Interview. A Manual of Problems and Procedures. Glencoe, IL: The Free Press.

Merton, R. K. and P. L. Kendall. 1946. 'The Focused Interview.' The American Journal of Sociology 51: 541-557.

Merton, R. K. and P. F. Lazarsfeld. [1943] 1968. 'Studies in Radio and Film Propaganda.' Pp. 563-582 in Social Theory and Social Structure, edited by R. K. Merton. New York: Free Press.

Neurath, P. 1978. 'Odds and Ends (from a Conversation with Pat Kendall)'. Paul Lazarsfeld Archive. Vienna. Unpublished manuscript.

Neurath, P. 1980. Paul Lazarsfeld 1901-1976 und die Entwicklung der empirischen Sozialforschung. Vienna: Institut für Soziologie der Sozial- und Wirtschaftswissenschaftlichen Fakultät der Universität Wien.

Neurath, P. 1998. 'The Life and Work of Paul Lazarsfeld.' Pp. 505-518 in Paul Lazarsfeld (1901-1976) La sociologie de Vienne à New York, edited by J. Lautman and B. P. Lécuyer. Paris and Montréal: L'Harmattan. 
Noelle-Neumann, E. 1983. Spiegel Dokumentation: Persönlichkeitsstärke. Hamburg: Spiegel Verlag.

Noelle-Neumann, E. 1985. 'Identifying Opinion Leaders.' Pp. 173-219 in 38th ESOMAR Congress, Proceedings, General Sessions.Wiesbaden, September.

Noelle-Neumann, E. and M. Csikszentmihalyi. 1992. 'Personality Strength: A New Variable for Opinion-Attitude Research.' Paper presented at the WAPOR Conference, St. Petersburg Beach, Florida, 15 May.

Peterman, J. N. 1940. “The "Program Analyzer": a New Technique in Studying Liked and Disliked Items in Radio Programs.' Journal of Applied Psychology 24 (6): 738-741.

Remr, J. 2008. 'Lazarsfeld's Contribution to Studying Attitudes in Evaluation Research.' Pp. 188-210 in Advanced Lazarsfeldian Methodology, edited by H. Jeřábek and P. Soukup. Prague: Karolinum.

Roosevelt, F. D. 1944. 'Greeting Letter from President Roosevelt.' Pp. x in Writers' Congress. The Proceedings of the Conference held in October 1943 under the sponsorhip of the Hollywood Writers' Mobilization and the University of California. Berkeley, Los Angeles, CA: University of California Press.

Siepmann, C. A. 1944. 'American Radio in Wartime.' Pp. 111-150 in Radio Research 1942-1943, edited by P. F. Lazarsfeld and N. Stanton. New York: Duell, Sloan and Pearce.

Sills, D. L. 1987. 'Paul F. Lazarsfeld 1901-1976. A Biographical Memoir.' Pp. 251-282 in Biographical Memoirs, Vol. 56. Washington, DC: The National Academy Press.

Simonson, P. and G. Weimann. 2003. 'Critical Research at Columbia: Lazarsfeld's and Merton's ,Mass Communication, Popular Taste, and Organized Social Action.' Pp. 12-38 in Canonic Texts in Media Research: Are There Any? Should There Be? How About These?, edited by Elihu Katz, J. D. Peters, T. Liebes and A. Orloff. Oxford: Wiley-Blackwell.

Simonson, P. 2004. 'Preface.' Pp. xi-xlv in Mass Persuasion. The Social Psychology of a War Bond Drive, edited by R. K. Merton, M. Fiske and Alberta Curtis. New York: Howard Fertig.

Simonson, P. 2005. 'The Serendipity of Merton's Communications Research.' International Journal for Public Opinion Research 17 (3): 277-297.

Simonson, P. 2010. Refiguring Mass Communication: A History. Champaign, IL: University of Illinois Press.

Speier, H. and Margaret Otis. 1944. 'German Radio Propaganda to France during the Battle of France.' Pp. 208-247 in Radio Research 1942-1943, edited by P. F. Lazarsfeld and N. Stanton. New York: Duell, Sloan and Pearce.

Sztompka, P. 1986. Robert K. Merton. An Intellectual Profile. New York: St. Martin's Press.

Weimann, G. 1991. 'The Influentials: Back to the Concept of Opinion Leaders?' Public Opinion Quarterly 55: 267-279.

Weimann, G. 1994. The Influentials. People Who Influence People. Albany, NY: State University of New York Press. 